\title{
Do Firms Hedge in Response to Tax Incentives?
}

\author{
JOHN R. GRAHAM and DANIEL A. ROGERS*
}

\begin{abstract}
There are two tax incentives for corporations to hedge: to increase debt capacity and interest tax deductions, and to reduce expected tax liability if the tax function is convex. We test whether these incentives affect the extent of corporate hedging with derivatives. Using an explicit measure of tax function convexity, we find no evidence that firms hedge in response to tax convexity. Our analysis does, however, indicate that firms hedge to increase debt capacity, with increased tax benefits averaging 1.1 percent of firm value. Our results also indicate that firms hedge because of expected financial distress costs and firm size.
\end{abstract}

AN INCREASING NUMBER OF CORPORATIONS use financial derivatives each year. The International Swaps and Derivatives Association reports that the notional value of outstanding OTC swap contracts increased from $\$ 11.3$ trillion in 1994 to more than $\$ 60$ trillion by mid-2000 (http://www.isda.org). This is interesting because financial theory tells us that corporate risk management enhances value only in the presence of costly market imperfections. A number of empirical studies examine derivative holdings to identify which of the proposed theoretical incentives and imperfections lead to corporate hedging. Our paper adds to the hedging literature by testing whether corporations respond to two tax-related incentives to hedge: the incentive to reduce volatility, thereby increasing debt capacity and the tax benefits of debt, and the incentive to reduce expected tax liabilities by reducing the volatility of taxable income. We also use a refined dependent variable to measure net

\footnotetext{
* Graham is from Duke University and Rogers is from Portland State University. We thank an anonymous referee, Tim Adam, Yiorgos Allayannis, Hank Bessembinder, Gordon Bodnar, Nick Bollen, Rick Green (the editor), David Haushalter, Eric Hughson, Ron Lease, Mike Lemmon, Uri Loewenstein, Steve Manaster, Mitchell Petersen, Jim Schallheim, Cathy Schrand, Betty Simkins, Cliff Smith, Jeremy Stein, René Stulz, Vicky Summers, Liz Tashjian, Wayne Thomas, Sheridan Titman, Bob Whaley, Jaime Zender, and seminar participants at the 2000 AFA meeting, California State University-Northridge, the 1999 EFA meeting, the 1999 FMA meeting, Fordham University, Marquette University, the 2000 National Tax Association meeting, Northeastern University, Oklahoma State University, the 2001 Rutgers conference on current concepts and evidence in capital structure, Southern Methodist University, University of Utah, Washington State University, the 2000 Western Finance meeting, and Wilfrid Laurier University for helpful comments and suggestions. We also appreciate the research assistance of Yong Cai, Lakshman Easwaran, Suzanne Perlee, and Ge Zhang. This paper builds upon Rogers' dissertation at the University of Utah. Graham acknowledges financial support from the Alfred P. Sloan Research Foundation. This paper previously circulated under the title "Is Corporate Hedging Consistent with Value Maximization? An Empirical Analysis."
} 
hedging and examine a number of nontax incentives to hedge. ${ }^{1}$ Finally, we add to the capital structure literature by showing that corporate hedging influences capital structure choices.

Smith and Stulz (1985) hypothesize that firms might hedge in response to tax function convexity. If the function that maps income into tax liability is convex, then by Jensen's Inequality, companies can reduce expected tax liabilities by hedging to reduce income volatility. This is an important and unresolved hypothesis, as evidenced by the fact that virtually every empirical study that investigates the use of derivatives includes a variable to proxy for tax function convexity. We argue that these variables do not measure tax function convexity very well. We use the Graham and Smith (1999) approach to explicitly calculate tax function convexity and find no relation between derivative holdings and convexity. This result is important because ours is the first direct examination of hedging and tax function convexity.

The second tax incentive to hedge is related to increasing debt capacity. Ross (1997) and Leland (1998) model the primary benefit of debt financing as the tax deductibility of interest and show that, by hedging, firms can increase debt capacity and therefore firm value. Stulz (1996) argues that hedging is used to reduce the probability of "left-tail" outcomes, thereby increasing debt capacity and interest deductions. We investigate hedging and debt policies jointly using simultaneous equations regressions. We find that leverage exerts a positive influence on the use of derivatives. Importantly, we also find that the debt-hedging relation runs the other way: Hedging leads to greater debt capacity. For the average firm, hedging with derivatives increases the debt ratio by 3 percent, with the capitalized value of the incremental tax shields equaling 1.1 percent of the market value of assets. This is the first evidence that hedging increases debt capacity and firm value. Moreover, to the best of our knowledge, our analysis provides the only explicit numerical estimate of value added due to derivatives hedging associated with a specific explanation of why firms hedge. ${ }^{2}$

Theoretical and empirical research shows that capital structure decisions are affected by, among other things, agency costs, informational asymmetry, industry conditions, and taxes (see Harris and Raviv (1991) and Graham (2001) for reviews). Our paper is the first to document that hedging deci-

\footnotetext{
${ }^{1}$ Schrand (1998) argues that hedging research can be grouped into two broad categories: (1) papers that investigate which market imperfections make volatility costly and therefore lead to corporate hedging, and (2) papers that investigate why one method of reducing volatility is cheaper than another. With respect to (1), the theories that model how these imperfections impose costs on the corporation generally do not specify the source of the volatility, nor which type of derivative instrument should be used to hedge. As examples of (2), Fenn, Post, and Sharpe (1996) and Visvanathan (1998) study which imperfections make it cheaper to use interest rate swaps in conjunction with short-term debt relative to issuing long-term debt. Our paper belongs in category one because we investigate which factors make volatility costly. Given that the theories do not specify which type of derivative should be used to reduce volatility, we test whether the factors outlined affect the incentive to hedge with either interest rate or currency derivatives.

${ }^{2}$ Allayannis and Weston (2001) find that hedging increases $q$-ratios by 4.9 percent.
} 
sions, as a right-hand-side variable, affect debt ratios. (Haushalter (2000) finds that debt ratios affect hedging decisions in the oil and gas industry and conjectures that the decisions are made jointly. We model the decisions as joint.) This result has important implications for capital structure research because it indicates that capital structure decisions are intertwined with other corporate decisions. Studies that ignore these interconnections risk omitting important variables and potentially make incorrect inferences about corporate decision making.

Among research that uses financial statements to identify the determinants of hedging, ours is the only study to examine net positions based on SFAS 119. ${ }^{3}$ Effective December 15, 1994, SFAS 119 required firms to report detailed information that makes it possible to net long and short positions. Prior to SFAS 119, notional values in financial statements were aggregated across derivative type, and therefore it was not possible to reliably net derivative positions. We conclude, however, that using net, as opposed to total, positions is only marginally important in helping identify factors that affect corporate hedging decisions. Finally, we study a broad cross section of firms, whereas most hedging papers examine only large, Fortune 500 types of firms. Overall, we find that large firms facing high expected distress costs (but not actually in extreme distress) hedge more with derivatives. We also use the measures of managerial motives proposed by Core and Guay (1999) and find that delta has a positive influence on corporate hedging, where delta is the sensitivity of the value of managerial stock and option holdings to a change in the firm's stock price.

The remainder of the paper is organized as follows. Section I reviews risk management theories and the related empirical evidence about why firms hedge, and defines the explanatory variables. Section II describes how we construct a sample of firms that face ex ante interest rate (IR) or foreign exchange (FX) risk. Section III performs the empirical analysis and Section IV concludes.

\section{Theoretical Explanations of Why Firms Hedge}

The Modigliani and Miller (1958) and Miller and Modigliani (1961) irrelevance propositions suggest that, in the absence of market imperfections, hedging does not increase firm value. If capital markets are perfect, shareholders possess the requisite tools and information to create their desired risk profiles, and therefore, there is no reason for a firm to hedge. If firms are exposed to economic risks in an imperfect environment, however, these exposures can impose costs on the corporation. For example, market imperfections can create an environment in which exposure to volatile interest rates is costly. Hedging helps reduce these costs. The remainder of this section describes imperfections and incentives that can provide incentives for companies to hedge.

\footnotetext{
${ }^{3}$ Wong (2000) uses SFAS 119 data to examine whether net notional value reliably measures currency exposure.
} 


\section{A. Tax Incentives to Hedge}

\section{A.1. Tax Function Convexity}

Smith and Stulz (1985) show that volatility is costly for firms with convex effective tax functions. To see this, assume that a firm is equally likely to lose $\$ 100,000$ or earn $\$ 100,000$ and that profits are taxed at 35 percent. Without hedging, even though expected income is zero, this firm expects to pay $\$ 17,500$ in taxes. If the firm can hedge to eliminate income volatility, expected income and taxes are zero. Though this example ignores features of the tax code that can reduce convexity (such as the ability to carry current losses forward to shield future profits from taxation), it illustrates how tax function convexity provides a tax incentive to hedge.

Most empirical derivatives papers measure tax function convexity with a variable based on existing net operating loss (NOL) carryforwards (e.g., Nance, Smith, and Smithson (1993), Tufano (1996), and Géczy, Minton, and Schrand (1997)). Such variables imply that firms with existing NOLs have convex tax functions, although the Smith and Stulz (1985) argument is about losses that firms expect to experience in the future. Graham and Smith (1999) document that existing NOLs provide a tax disincentive to hedge for companies with expected losses (if a firm expects to lose money, hedging reduces "right-tail" outcomes and the chance that the firm will use its existing NOLs) but provide an incentive to hedge for companies that expect to be profitable. Thus, variables based on existing NOLs are too simple to capture incentives that result from the shape of the tax function, and can work backwards for expected loss firms. In unreported analysis, we find that NOL carryforwards are uncorrelated with tax function convexity (the Pearson correlation between the two variables is negative one percent). In addition, existing NOLs might measure financial distress or some other characteristic, rather than a tax incentive to hedge.

Rather than using a NOL variable, we use the Graham and Smith (1999) approach and explicitly measure tax function convexity. This technique quantifies the convexity-based benefits of hedging by determining the tax savings that result from reducing volatility. We first calculate expected tax liability for a "full volatility" case, and then recalculate expected tax liability with volatility reduced by five percent; the difference between these two numbers represents the convexity-based tax benefit of hedging. We choose a five percent volatility reduction to be consistent with the risk reduction observed by Guay (1999) when firms introduce hedging programs. ${ }^{4}$ (Our qualitative results do not change if we use a one percent or three percent volatility re-

\footnotetext{
${ }^{4}$ The reported analysis is based on volatility of sales revenue. Although Graham and Smith (1999) show that convexity does not differ substantially for different measures of earnings, previous readers of our paper suggested that taxable earnings might be affected by a firm's past hedging program, while sales revenue should not be directly affected. Therefore, we base our analysis on sales revenue volatility. Our qualitative results are unchanged if we base volatility on taxable earnings.
} 
duction.) In regression analysis, we scale this dollar value convexity-based tax benefit by sales. Our variable is the only explicit measure of tax convexity used in any empirical derivatives paper.

In Section II, we argue that the magnitude and variation of convexity tax savings are sufficient to allow statistical identification if firms hedge in response to tax convexity; however, there are countervailing economic influences against this type of hedging. Graham and Smith (1999) show that the firms that are most likely to have convex functions are small, have expected income near zero, and alternate between profits and losses. These firms might find the fixed costs of setting up a hedging program prohibitive, and consequently not hedge..$^{5}$ In addition, these firms may be in or near financial distress, thus providing shareholders incentive to increase volatility, opposite the incentive provided by the tax code.

\section{A.2. Hedging to Increase Debt Capacity}

Stulz (1996), Ross (1997), and Leland (1998) show that, by reducing the volatility of income and/or reducing the probability of financial distress, hedging increases debt capacity. If firms add leverage in response to greater debt capacity, the associated increase in interest deductions reduces tax liabilities and increases firm value. Thus, the ability to increase debt capacity provides a tax incentive to hedge.

Specifically, in his Presidential Address to the American Finance Association, Leland (1998) argues that hedging increases value through two different channels related to debt usage. The principal gain comes from "the fact that lower average volatility allows higher leverage with consequently greater tax benefits." A secondary hedging gain comes from "lower expected default rates" and distress costs, resulting from unused debt capacity. That is, the majority of the gain comes from increased leverage/tax deductions but a portion of the increased debt capacity goes unused, resulting in lower distress costs, which also increases firm value. Ross (1997) also argues that the reduction in expected distress costs is less important than the tax shield from increased leverage.

\section{B. Nontax Incentives to Hedge}

\section{B.1. Expected Costs of Financial Distress}

If financial distress is costly, Smith and Stulz (1985) argue that hedging can increase firm value by reducing volatility and the probability of distress. Froot, Scharfstein, and Stein (1993) endogenize distress costs and show that hedging can reduce the underinvestment problem resulting from the dead-

\footnotetext{
${ }^{5}$ Bodnar, Hayt, and Marston (1996) find that firms report "costs of establishing and maintaining a derivatives program exceed the expected benefits" as the second most common explanation for not using derivatives.
} 
weight costs associated with external financing. Stulz (1996) emphasizes the role of hedging in preventing left-tail outcomes that force firms to bypass investment opportunities.

Many papers use the debt ratio to measure expected costs of distress and find that hedging increases with the debt ratio (e.g., Dolde (1995) and Haushalter (2000)). We include the debt ratio in our analysis, defined as total debt divided by the book value of assets. Most studies interpret a positive debt coefficient as evidence that greater expected financial distress costs cause greater hedging, which assumes that firms with higher debt ratios face higher probabilities of encountering financial distress. It is important to emphasize that theory indicates that the hedging/leverage causality can go both ways: Hedging can increase debt capacity, but higher leverage (to the extent that it increases the probability of distress) can increase the incentive to hedge. Therefore, we model the hedging/capital structure decision as a simultaneous system, which is appropriate if these two corporate policies are jointly determined. In the regressions with hedging as the dependent variable and debt on the right-hand side, we interpret a positive coefficient as evidence that leverage leads to increased hedging due to higher expected costs of distress. In the regressions with debt as the dependent variable and derivatives on the right-hand side, we interpret a positive coefficient as evidence that hedging increases debt capacity and tax deductions.

We also measure expected distress costs with a variable that accounts for both the probability of distress and the associated cost if distress occurs. To calculate this variable, we multiply the debt ratio by the equity market-tobook ratio. The probability of financial distress increases with the debt ratio. The cost of distress (if encountered) increases with the market-book ratio (in a Myers (1977) sense, because of the potential to miss out on growth opportunities if distress is encountered). We expect to observe a positive relation between this variable and derivatives use if firms hedge in response to distress costs. ${ }^{6}$

\section{B.2. Underinvestment Costs}

Hedging can reduce underinvestment problems (Myers (1977) and Myers and Majluf (1984)). Bessembinder (1991) argues that if a firm can credibly commit to a hedging policy at the time of a financing decision, the under-

\footnotetext{
${ }^{6}$ We examine three other distress cost variables. Profitability might be inversely related to hedging if less profitable firms have a higher probability of encountering distress. Conversely, the option value of equity might encourage unprofitable firms to hedge less than their nondistressed counterparts. We measure profitability as the pretax return on assets (ROA). We also identify firms that might be experiencing current (or recent) financial distress with NOL carryforwards scaled by the book value of assets. Finally, we include a variable defined as the book-market of equity if negative, and zero otherwise. Negative book equity often indicates that a firm is very distressed, which might indicate that hedging is unlikely because it reduces the option value of equity.
} 
investment problem is attenuated because the value of debt becomes less sensitive to incremental investment decisions. In Froot et al. (1993), volatility is costly because positive NPV projects may be rejected if internal funds are relatively scarce in some states of nature. Hedging allows a firm to shift internal funds into states where they would otherwise be scarce. If internal funds are cheaper than external funds, hedging permits the company to finance valuable investment projects and increase firm value. ${ }^{7}$

The underinvestment problem is most severe for firms with valuable investment opportunities, which we quantify with the market-book ratio. Several empirical studies examine the relation between market-book and hedging and find no relation (e.g., Mian (1996) and Allayannis and Ofek (2001)). We also include the product of the market-book ratio and the debt ratio in our specification, which Géczy et al. (1997) define as a measure of underinvestment costs. We also use R\&D spending scaled by book assets to measure growth options. Several papers find that hedging increases with R\&D spending (e.g., Dolde (1995) and Géczy et al.). Finally, we include cash capital expenditures on property, plant, and equipment, scaled by the book value of assets, to control for the relation between hedging and current investment spending.

\section{B.3. Managerial Risk Aversion}

If managers have concave utility functions, and the variability of their compensation is related to the volatility of corporate income or cash flows, then corporate volatility can be costly (Stulz (1984) and Smith and Stulz (1985)). If managers cannot effectively hedge corporate volatility in their personal accounts, or if it is cheaper for the firm to hedge than it is for managers, then corporate hedging can improve managerial welfare. Corporate hedging can be optimal if it reduces the risk premium managers demand, and likewise reduces required compensation. Tufano (1996) and Schrand and Unal (1998) find evidence that hedging increases with managerial shareholdings and decreases with managerial option ownership, consistent with the hypotheses outlined above. Other studies (e.g., Géczy et al. (1997) and Haushalter (2000)) find no evidence that managerial risk aversion or shareholdings affect corporate hedging.

We use the vega variable defined in Core and Guay (1999) to gauge executive incentives to alter firm risk. Vega (per option) is the partial derivative of the dividend-adjusted Black-Scholes value of CEO stock options with respect to volatility, multiplied by one percent. The product of vega and the

\footnotetext{
7 Tufano (1998) argues that managers might hedge to avoid scrutiny of negative NPV "pet projects" by external capital markets. Providers of external capital would not fund these pet projects. However, if managers use hedging to ensure the availability of internal capital, then the projects might be funded. Tufano thus suggests that hedging can lead to overinvestment. However, Tufano notes that if "pet project" agency costs are relatively low, then underinvestment concerns will dominate.
} 
number of options held by the CEO equals the value change in the CEO's stock option holdings resulting from a one percent increase in stock return standard deviation. We scale vega by the sum of the CEO's salary and bonus. Executives benefit from increased volatility when vega is high, so we expect a negative relation between vega and risk management (if managerial motives affect cross-sectional differences in corporate hedging). We also examine whether delta (the value change in the CEO's stock and option portfolio resulting from a one percent change in the firm's stock price) affects corporate hedging. We use the Core and Guay measure of delta, scaled by the CEO's salary plus bonus. Executives with large deltas have exposure similar to holding stocks and/or in-the-money options, and therefore may have more exposure to idiosyncratic risk, which they can reduce by hedging. This would lead to a positive relation between delta and corporate hedging.

\section{B.4. Other Incentives to Hedge}

DeMarzo and Duffie (1991) and Breeden and Viswanathan (1998) assume that informational asymmetries exist between managers and shareholders. DeMarzo and Duffie argue that firms should sometimes hedge based on private information that cannot be conveyed costlessly to shareholders. Breeden and Viswanathan argue that a high-quality manager has incentive to hedge away uncertainty about her performance so that the market can more precisely infer her ability. To measure the degree of information asymmetry, we use the portion of each firm's shares that are owned by institutions as of September 1994, based on 13-f filings reported by CDA Spectrum. If firms owned primarily by institutions face less informational asymmetry of the type assumed by DeMarzo and Duffie and Breeden and Viswanathan, their theories imply that high-institution-ownership firms should hedge less. Géczy et al. (1997) find the opposite, namely that firms with high institutional ownership are more likely to hedge with currency derivatives.

Most prior studies find that the likelihood of using derivatives increases with firm size. A positive size effect is consistent with firms not hedging with derivatives unless the benefits are larger than the fixed costs of establishing a hedging program. We measure firm size as the natural logarithm of total assets. Also, Nance et al. (1993) note that "hedging substitutes" can reduce the need for hedging. For example, dividend restrictions might allow a firm to retain sufficient liquidity to make hedging unnecessary. Dividend yields (Nance et al.) and liquidity ratios (Tufano (1996) and Géczy et al. (1997)) have both been shown to be negatively related to derivatives usage. We also examine the effect of these variables on derivatives hedging.

As mentioned in footnote 1 , some papers study the factors that make using interest rate swaps in conjunction with short-term debt preferable to using long-term debt. We control for this possibility by including the sum of short-term and floating-rate debt (as a percentage of total debt) in our regressions to control for the effect of such debt on interest rate 
derivatives use. ${ }^{8}$ We also control for the importance of foreign sales relative to total sales. Allayannis and Ofek (2001) use the foreign sales ratio as a measure of the extent of foreign currency exposure, and report a positive relation between this variable and foreign currency derivative holdings.

\section{Derivatives Data and Construction of Hedging Variables}

\section{A. Sample Formation}

We analyze corporate derivative holdings as of calendar-year-end 1994 or fiscal 1995. This time frame is chosen because, prior to December 1994, financial statement disclosures were generally inadequate to analyze the extent of derivatives hedging. ${ }^{9}$ In 1994, the Financial Accounting Standards Board (FASB) issued SFAS 119 in an attempt to improve derivative disclosures by U.S. corporations. SFAS 119 mandates that firms disclose information on notional values of derivative contracts, including the direction of the position, across several categories. SFAS 119 became effective for fiscal years ending after December 15, 1994, for firms with assets greater than $\$ 150$ million. ${ }^{10}$ Firms are required to specify if derivatives are held for trading purposes or, if for nontrading reasons, the purpose of the holdings. We only examine derivatives held for nontrading purposes.

We obtain the information about each firm's fiscal year-end derivatives ownership from 10-K forms filed electronically in the SEC's Electronic Data Gathering and Retrieval (EDGAR) database from March through December 1995. This population consists of 3,232 firm-filings. We search the footnotes and Management's Discussion and Analysis (MD\&A) of each 10-K filing for text strings such as "hedg," "swap," and "derivative." If a reference is made to any of the search terms, we read the surrounding text to confirm that it refers to derivative holdings. Given the time-consuming nature of data collection from these filings, we examine a random sample of 855 firms selected from the initial list of filers. Out of these 855 firms, we retain observations that meet the following criteria:

\footnotetext{
8 To control for another explanation of why firms use swaps and short-term debt, we examine the level of credit ratings to see if low-quality firms use IR derivatives to avoid the "credit quality spread" associated with issuing long-term debt (Bicksler and Chen, 1986). We also examine changes in future credit ratings, to see if firms with favorable private information use short-term debt and IR swaps until their credit ratings improve (Titman (1992)). These two hypotheses are not supported by our evidence, and yet including the credit rating reduces sample size, so we do not include credit ratings in our reported results.

${ }^{9}$ Prior to December 1994, derivative holdings from financial statements did not permit accurate netting of long and short positions because the reported notional values were usually aggregated across different types of derivatives.

${ }^{10}$ SFAS 105 and 107 require firms to declare if they use derivatives, even if their assets are less than $\$ 150$ million.
} 
1. fiscal year ends December 15, 1994, through October 31, 1995;

2. complete set of annual financial statements including footnotes is available;

3. the firm is not a subsidiary of another firm in the sample;

4. the firm's income is taxable at the corporate level;

5. the firm is listed on the COMPUSTAT annual database;

6. the firm discloses the notional value of its derivative holdings, if any; and

7. the firm is not financial (SIC codes 60 to 69 ).

Of the 469 firms meeting these criteria, we study the 442 that face ex ante currency and/or interest rate risk (as described in the next section).

\section{B. Definition of Ex Ante Risk Exposure}

By focusing on firms that face ex ante risk, we can interpret the absence of derivatives as a choice not to use derivatives, rather than possibly indicating a lack of exposure to hedgeable risks. Similar to previous research, we define firms to have ex ante currency exposure if they disclose foreign assets, sales, or income in the COMPUSTAT Geographic segment file, or disclose positive values of foreign currency adjustment, exchange rate effect, foreign income taxes, or deferred foreign taxes in the annual COMPUSTAT files. ${ }^{11}$

We define ex ante interest rate risk based in part on the sensitivity of operating income to interest rates. Specifically, we regress changes in operating income on changes in the six-month LIBOR rate. (Operating income does not usually contain income resulting from interest rate derivatives, and therefore should not be endogenously affected by the decision to hedge with interest rate derivatives.) We use seven years of quarterly data for each firm's regression. Based on the sign of the regression coefficient, we classify firms as having positive, negative, or zero operating exposure to interest rates. Zero exposure occurs when the regression coefficient is not significant at the 10 percent level. A firm faces ex ante interest rate risk if it meets any of the following criteria:

1. zero operating exposure to interest rate changes and positive amounts of floating debt (i.e., short-term and/or floating-rate debt);

2. negative operating exposure to interest rate changes; or

3. positive operating exposure to interest rate changes and less than 50 percent of debt is floating. (Floating debt can offset positive operating exposure to interest rates, thereby attenuating interest rate risk.)

${ }^{11}$ We note but do not investigate the possibility that a firm might be subject to foreign exchange risk due to its competitive environment, even if it does no business outside the United States. 
Fifty-one of the sample firms do not face interest rate risk; however, 24 of these 51 firms face ex ante currency risk. On net, we delete 27 firms because they face neither IR nor FX risk. The results presented below do not change qualitatively if we include these 27 firms. ${ }^{12}$

\section{Measuring Derivatives Hedging}

We gather notional values for interest rate and currency derivatives and classify the positions as "long" or "short." 13 A long interest rate position is one that benefits from rising interest rates, such as an interest rate swap that pays a fixed rate and receives a floating rate. Conversely, a short interest rate position benefits from declining interest rates. A long currency derivative position benefits from price increases of a currency other than the U.S. dollar, while a short currency derivative position benefits from decreasing foreign currency prices. If a position is not clearly long or short, we classify it as "unsure."

We measure derivative holdings several ways. One measure is the total notional value of derivative contracts held by each firm for nontrading purposes. Total notional values have recently been used in Berkman and Bradbury (1996), Gay and Nam (1999), and Allayannis and Ofek (2001). We calculate total notional values for IR holdings and, separately, for total notional FX holdings.

While total notional value effectively gauges derivatives ownership, it may not accurately estimate derivatives hedging if a firm holds offsetting contracts. The distinction between ownership and hedging is important when testing theories of risk management. Therefore, for our second derivatives variable, we calculate the absolute values of net derivative positions in each category. The net position is the difference between each firm's long and short positions in interest rate and, separately, individual currency derivatives. ${ }^{14}$ For interest rate positions, we add basis swaps (interest rate swaps that are essentially an exchange of floating rate indices) to the absolute difference between long and short positions. We use the net derivatives variable for most of our analysis.

\footnotetext{
${ }^{12}$ Our IR risk definition focuses on variable rate debt and identifies operational sensitivity to changes in interest rates. It is also true that the value of fixed rate debt is sensitive to interest rates. In the robustness section, we examine an alternative definition of interest rate sensitivity that partially addresses the sensitivity of fixed rate debt.

${ }^{13}$ We ignore commodity derivatives because they are not considered derivative financial instruments under SFAS 119 because of the possibility of physical delivery (such as with commodity futures contracts). Thus, disclosure of commodity derivatives is not consistent across firms.

14 The total notional value used in previous derivatives studies might classify $\$ 100$ million long and $\$ 50$ million short as $\$ 150$ million. In contrast, we net the two figures to determine a net position of $\$ 50$ million. Wong (2000) finds that net notional values are related to foreign currency exposure in 1995.
} 
Finally, to contrast our analysis with studies that examine the yes/no hedging decision, we construct a binary variable. Firms that hold derivatives for nontrading purposes are assigned a value of one for the binary variable, and all other firms are assigned a value of zero.

Because most of the theories of why volatility is costly do not differentiate between which derivative security is used to hedge, we use the sum of net interest rate and currency positions as the dependent variable in our primary regression analyses. ${ }^{15}$ However, in unreported analyses, we repeat our tests on firms in the ex ante IR risk sample (and separately, we analyze the firms facing ex ante FX risk) that use interest rate (currency) derivative instruments to hedge. We also experiment with using total notional values (and separately, the binary hedging variable) as the dependent variable for the full sample, as well as the separate IR and FX samples. Our important findings with respect to the tax incentives to hedge are unchanged in these separate analyses; therefore, we only report results for a few of these robustness checks.

Three important issues affect how precisely our variables measure corporate hedging. First, derivative holdings may measure speculative activity, not hedging. Taken literally, SFAS 119 requires firms to explicitly state if they speculate with derivatives. Many firms provide statements such as "derivatives are used for risk management purposes only"; however, none of the sample firms state that they speculate. Further, our variables are defined using only those derivatives disclosed as being held for nontrading purposes. Consequently, we classify firms that use derivatives for nontrading purposes as "hedgers" and those that do not use derivatives for nontrading as "nonusers." 16 Second, firms can hedge with operational strategies, such as building a manufacturing facility in a locale that is the source of foreign currency risk, or by issuing convertible debt. Our study investigates why firms hedge with derivatives beyond any hedging they may accomplish with operational strategies.

Finally, as noted by Smith (1995), different firms can hold the same notional value of derivatives and still have very different hedging practices. For example, two firms may hold $\$ 10$ million in derivatives, but one has one-year swaps and the other seven-year swaps. The firm with the one-year

\footnotetext{
${ }^{15}$ For example, consider a firm with notional values of $\$ 100$ million long interest rate, $\$ 50$ million short interest rate, $\$ 20$ million long British pounds, and $\$ 75$ million short Japanese yen. This firm's net position in IR (FX) derivatives is \$50 (\$95) million. We use absolute values because hedging to maximize firm value may require going long in one derivatives category but short in another. The dependent variable in our primary regression analysis is the sum of net absolute IR and FX holdings, $\$ 145$ million in this example.

${ }^{16}$ Several studies lead us to believe that most corporate derivatives are held as hedging instruments. Guay (1999) finds that initiation of corporate derivatives use is associated with declines in various measurements of firm risk. Allayannis and Ofek (2001) show that using derivatives reduces currency exposure. Tufano (1996) finds no evidence of speculation among U.S. gold mining firms. Hentschel and Kothari (2001) find no evidence that derivatives increase firm risk. However, Bodnar et al. (1996) report that corporate management teams sometimes allow their "market view" to influence hedging decisions, implying that there may be an element of speculation in any sample of corporate derivative holdings.
} 
swap might appear to hedge less than its counterpart with the seven-year swap. However, if the first firm is hedging a liability that matures in one year while the other is hedging a liability that matures in seven years, then both firms might be hedging appropriately. Current financial reporting guidelines do not require firms to disclose the underlying asset and/or liability that is being hedged with a derivative contract, so we are unable to determine whether firms employ a duration-matching hedging policy. To the extent that notional values do not fully reflect corporate hedging practices, our data are noisy, which works against our ability to document hedging incentives.

Table I shows that 158 out of 442 firms in the sample disclose some type of derivative holdings. For these 158 derivative users, the mean (median) total notional value is $\$ 1,143$ (\$104) million, or 13.16 percent (8.79 percent) of total assets. We can calculate net derivative positions for 136 firms. The mean (median) net position is $\$ 280$ (\$80) million, or 9.28 percent (7.31 percent) of total assets. ${ }^{17}$ The summary statistics for the explanatory variables in the hedging equation are presented in Table II. Of particular interest, the convexity variable exhibits substantial cross-sectional variation. Also, the mean convexity-based incentive is larger in our sample than is the mean documented in Graham and Smith (1999) for all COMPUSTAT firms. Therefore, our sample seems to be a reasonable place to investigate whether firms hedge in response to tax function convexity.

\section{Empirical Analysis of Corporate Hedging and Debt Policy}

In this section, we use multivariate regressions to examine corporate debt and hedging policies. In Section A, we use simultaneous equations because the theories discussed earlier suggest that hedging can increase the capacity to use debt, and simultaneously debt can affect hedging policy. In Section B, we perform robustness checks on the basic results.

\section{A. Simultaneous Equations Regressions}

We use a two-stage estimation procedure in our simultaneous equations model. In the first stage, two separate regressions are performed using derivatives hedging and the debt ratio, respectively, as dependent variables. For the first-stage hedging specification, we estimate a Tobit regression (because the dependent variable is censored at zero) using net derivatives (scaled by the book value of assets) as the dependent variable. ${ }^{18}$ The coefficients for

\footnotetext{
${ }^{17}$ We exclude from the primary regression analysis firms that have positive total derivatives but are missing a net derivatives position.

18 The parameter estimates from a Tobit regression represent the marginal effect of each regressor on the unobserved dependent variable, $Y_{i}^{*}$. We are more interested in the marginal effect on the observed dependent variable, $Y_{i}$. The marginal effect of a change in the $k$ th regressor is calculated by $F(z) \beta_{k}$, where $F(z)$ is the normal CDF evaluated at $z=\beta^{\prime} X_{i} / \sigma, X_{i}$ is the vector of independent variables, and $\beta_{k}$ is the vector of coefficients. The marginal effects are calculated at the means of the independent variables (as described in Maddala (1983)).
} 


\section{Table I}

\section{Notional Values of Contracts Held by Derivative Hedgers}

Table I provides descriptive statistics of the derivative positions held by sample firms at the end of fiscal 1994 or 1995. Total derivative positions are the sum of notional values of interest rate (IR) and foreign currency (FX) derivative contracts. Net positions are the sum of absolute net positions in IR and FX derivatives. Net interest rate derivatives are the absolute difference between long and short IR derivatives, plus IR basis swaps. Net foreign currency derivatives are the sum of absolute differences between long and short positions across all currencies. The table also shows descriptive statistics on long, short, and unsure interest rate and foreign currency derivatives. All values are in millions of dollars.

\begin{tabular}{|c|c|c|c|c|c|c|c|}
\hline Derivative Type & Position Type & $N$ & Mean & $\begin{array}{l}\text { Std. } \\
\text { Dev. }\end{array}$ & Min. & Max. & Median \\
\hline \multicolumn{2}{|c|}{ Total derivative positions } & 158 & 1,143 & 5,692 & 1 & 66,400 & 104 \\
\hline \multicolumn{2}{|l|}{ Scaled by assets } & & $13.16 \%$ & $13.31 \%$ & $0.16 \%$ & $86.32 \%$ & $8.79 \%$ \\
\hline \multicolumn{2}{|l|}{ Net positions } & 136 & 280 & 501 & 0 & 3,342 & 80 \\
\hline \multicolumn{2}{|l|}{ Scaled by assets } & & $9.28 \%$ & $9.49 \%$ & $0.00 \%$ & $53.84 \%$ & $7.31 \%$ \\
\hline \multirow[t]{12}{*}{ Interest rate } & Long & 91 & 241 & 348 & 3 & 1,759 & 92 \\
\hline & Scaled by assets & & $8.10 \%$ & $7.96 \%$ & $0.28 \%$ & $35.23 \%$ & $5.85 \%$ \\
\hline & Short & 43 & 424 & 576 & 5 & 2,900 & 176 \\
\hline & Scaled by assets & & $7.29 \%$ & $6.30 \%$ & $0.22 \%$ & $21.94 \%$ & $5.68 \%$ \\
\hline & Basis swaps & 4 & 237 & 185 & 50 & 492 & 203 \\
\hline & Scaled by assets & & $3.89 \%$ & $2.89 \%$ & $0.98 \%$ & $7.86 \%$ & $3.35 \%$ \\
\hline & Unsure & 12 & 6,647 & 15,822 & 5 & 53,800 & 300 \\
\hline & Scaled by assets & & $12.57 \%$ & $18.19 \%$ & $0.69 \%$ & $63.28 \%$ & $4.90 \%$ \\
\hline & Total & 110 & 1,099 & 5,437 & 3 & 53,800 & 119 \\
\hline & Scaled by assets & & $11.06 \%$ & $11.12 \%$ & $0.29 \%$ & $63.28 \%$ & $7.70 \%$ \\
\hline & Net & 108 & 227 & 414 & 0 & 2,900 & 85 \\
\hline & Scaled by assets & & $7.24 \%$ & $7.46 \%$ & $0.00 \%$ & $35.23 \%$ & $5.08 \%$ \\
\hline \multirow[t]{10}{*}{ Foreign currency } & Long & 54 & 210 & 385 & 1 & 1,909 & 59 \\
\hline & Scaled by assets & & $5.99 \%$ & $8.64 \%$ & $0.00 \%$ & $46.77 \%$ & $2.59 \%$ \\
\hline & Short & 41 & 246 & 374 & 1 & 1,495 & 67 \\
\hline & Scaled by assets & & $6.58 \%$ & $7.62 \%$ & $0.11 \%$ & $36.14 \%$ & $4.89 \%$ \\
\hline & Unsure & 46 & 833 & 2,183 & 1 & 12,600 & 108 \\
\hline & Scaled by assets & & $5.85 \%$ & $5.55 \%$ & $0.16 \%$ & $23.84 \%$ & $4.01 \%$ \\
\hline & Total & 107 & 558 & 1,534 & 1 & 12,600 & 74 \\
\hline & Scaled by assets & & $8.06 \%$ & $9.28 \%$ & $0.14 \%$ & $51.35 \%$ & $5.17 \%$ \\
\hline & Net & 77 & 177 & 301 & 0 & 1,605 & 59 \\
\hline & Scaled by assets & & $6.23 \%$ & $8.37 \%$ & $0.00 \%$ & $46.77 \%$ & $3.43 \%$ \\
\hline
\end{tabular}

the variables measuring capital expenditures, credit ratings, industry dummies, return on assets, dividend yield, and the quick ratio are not statistically significant in this stage, so we delete these controls from the hedging specification. Our conclusions are not affected by excluding these variables. 


\section{Table II}

\section{Explanatory Variables-Summary Statistics}

Table II provides summary information for the independent variables used in the analysis. Tax convexity is the dollar tax benefit from a five percent volatility reduction, scaled by sales revenue. Debt-to-assets is the ratio of debt to book value of assets. Debt ratio $\times$ market-book is the debt ratio multiplied by the market-book ratio of equity. $R \& D$-to-assets is research and development expense scaled by book value of assets. Capital expenditures-to-assets is dollars spent on capital expenditures scaled by book value of assets. Book-market of equity is the book-market ratio of equity. Dividend yield is annual dividend divided by year-end stock price. Quick ratio is current assets minus inventory, the difference divided by current liabilities. Floating rate debtto-total-debt is the sum of debt in current liabilities plus long-term floating rate debt, scaled by total debt. Foreign sales (scaled by total sales) is the ratio of foreign sales to total sales. Total assets are represented as the book value of assets. Pretax ROA is earnings before taxes scaled by book value of assets. NOL carryforwards-to-assets are net operating loss carryforwards scaled by book value of assets. Institutional ownership pct. is the percentage of common shares owned by institutional investors. Delta represents the dollar change in value of the CEO's stock and option portfolio from a one percent increase in stock price (scaled by the CEO's salary + bonus). Vega represents the dollar change in value of the CEO's option portfolio from a one percent increase in the standard deviation of the firm's stock returns (scaled by the CEO's salary + bonus).

\begin{tabular}{lrrrrrr}
\hline \multicolumn{1}{c}{ Variable } & & & & Std. & \\
& $N$ & Mean & Median & Dev. & Min. & Max. \\
\hline Tax convexity (dollars) & 410 & 0.4478 & 0.0388 & 2.6233 & -6.9485 & 40.9785 \\
Tax convexity (scaled by sales) & 410 & 0.0011 & 0.0001 & 0.0150 & -0.0017 & 0.3038 \\
Debt-to-assets & 442 & 0.2971 & 0.2778 & 0.2307 & 0.0000 & 2.3835 \\
Debt ratio $\times$ market-book & 418 & 0.7290 & 0.3894 & 3.3171 & -12.3891 & 36.9232 \\
R\&D-to-assets & 432 & 0.0275 & 0 & 0.1189 & 0 & 1.8884 \\
Capital expenditures-to-assets & 437 & 0.0668 & 0.0538 & 0.0604 & 0 & 0.7210 \\
Book-market of equity & 418 & 0.4622 & 0.5677 & 2.4329 & -46.7768 & 6.1415 \\
Dividend yield & 419 & 0.0197 & 0.0071 & 0.0503 & 0 & 0.9174 \\
Quick ratio & 425 & 0.4437 & 0.1362 & 0.9402 & 0 & 8.2052 \\
Floating rate debt-to-total debt & 424 & 0.3625 & 0.2367 & 0.3467 & 0 & 1.7901 \\
Foreign sales (scaled by total sales) & 442 & 0.0976 & 0 & 0.1807 & 0 & 1.0000 \\
Book value of assets & 442 & 2905.0 & 474.7 & 11892.8 & 0.8 & 198938.0 \\
Pretax ROA & 442 & 0.0547 & 0.0676 & 0.1408 & -1.7866 & 0.3792 \\
NOL carryforwards-to-assets & 442 & 0.0443 & 0 & 0.2428 & 0 & 3.0364 \\
Institutional ownership pct. & 400 & 0.4197 & 0.4231 & 0.2355 & 0.0026 & 0.9038 \\
Delta (scaled by the CEO's salary + bonus) & 401 & 0.3249 & 0.0788 & 1.1854 & 0 & 14.7054 \\
Vega (scaled by the CEO's salary + bonus) & 401 & 0.0232 & 0.0109 & 0.0437 & 0 & 0.4626 \\
\hline
\end{tabular}

The first-stage debt ratio equation is estimated with ordinary least squares (OLS). ${ }^{19}$ The debt specification uses explanatory variables suggested by Titman and Wessels (1988) and Graham, Lemmon, and Schallheim (1998), as described in Table III. In addition, the debt equation explores whether the extent of derivatives hedging is an important determinant of debt policy.

19 The results do not change if we model the debt equation as a Tobit regression rather than with OLS. Only 14 of 324 observations are censored at zero in the first stage, and no observations are censored in the second-stage debt equation. 


\section{Table III}

\section{Simultaneous Equations Analysis of Debt and Hedging Decisions}

Table III shows the results of structural models linking the extent of derivatives hedging with the debt ratio. The upper portion of Model 1 shows the results of second-stage Tobit estimation of net derivatives scaled by book value of assets on explanatory variables, including the predicted value of the debt-to-assets ratio and the predicted debt ratio multiplied by the marketbook ratio. Debt ratio* $\times$ market-book is the predicted debt ratio from the untabulated first stage regression multiplied by market-book. The other variables used in the upper portion of the table are described in the caption to Table II. The lower portion of Model 1 shows the results of second-stage OLS estimation of the debt-to-asset ratio on the predicted value of net derivatives scaled by book value of assets and other variables explaining debt levels. Investment tax credits are investment tax credits scaled by book value of assets. Intangible assets are book value of intangible assets as a percentage of book value of total assets. $R \& D$-to-assets is research and development expense as a percentage of net sales revenues. $S G \& A$ expense is selling, general, and administrative expense as a percentage of net sales revenues. $\log ($ Sales $)$ is the natural logarithm of net sales revenues. Volatility is the absolute coefficient of variation of taxable income. Marginal tax rate $(M T R)$ is the before-financing simulated marginal tax rate used in Graham, Lemmon, and Schallheim (1998). Net derivatives* $\times M T R$ is predicted net derivatives from the untabulated first-stage regression multiplied by MTR. Negative bookmarket dummy equals to one if the book value of shareholders' equity is negative. Net PP\&E is book value of property, plant, and equipment, net of depreciation as a percentage of book value of total assets. Model 2 is the same as Model 1 except that it also includes an explanatory variable in the debt equation that interacts derivative holdings with the corporate marginal tax rate. $P$-values in the debt regression are computed with heteroskedastic consistent standard errors. Slope estimates are shown for the Tobit regressions. The slope estimates represent the marginal effects of changes in the independent variables on the value of the observed dependent variable, calculated at the mean levels of the independent variables.

\begin{tabular}{|c|c|c|c|c|}
\hline \multirow[b]{2}{*}{ Explanatory variables } & \multicolumn{2}{|c|}{ Model 1} & \multicolumn{2}{|c|}{ Model 2} \\
\hline & $\begin{array}{c}\text { Slope } \\
\text { Estimate }\end{array}$ & $p$-value & $\begin{array}{c}\text { Slope } \\
\text { Estimate }\end{array}$ & $p$-value \\
\hline \multicolumn{5}{|c|}{ Dependent variable: Net derivatives scaled by assets } \\
\hline Intercept & -0.0892 & 0.0001 & -0.0877 & 0.0001 \\
\hline Tax convexity & -2.7909 & 0.4505 & -2.9888 & 0.4189 \\
\hline Debt-to-assets* & 0.1031 & 0.0001 & 0.1029 & 0.0001 \\
\hline Debt ratio* $\times$ market-book & 0.0024 & 0.0106 & 0.0023 & 0.0141 \\
\hline R\&D-to-assets & -0.0445 & 0.0270 & -0.0451 & 0.0261 \\
\hline Book/market of equity & 0.0212 & 0.0001 & 0.0210 & 0.0001 \\
\hline Negative book-market & -0.0201 & 0.0002 & -0.0200 & 0.0003 \\
\hline Floating rate debt-to-assets & 0.0080 & 0.1344 & 0.0079 & 0.1367 \\
\hline Foreign sales (\% of sales) & 0.0210 & 0.0380 & 0.0212 & 0.0360 \\
\hline $\log (\mathrm{BV}$ of assets) & 0.0046 & 0.0002 & 0.0045 & 0.0003 \\
\hline NOL carryforwards-to-assets & -0.1968 & 0.0109 & -0.1991 & 0.0098 \\
\hline Institutional ownership pct. & 0.0175 & 0.0411 & 0.0162 & 0.0567 \\
\hline Delta (\% of the CEO's salary + bonus) & 0.0036 & 0.0820 & 0.0037 & 0.0726 \\
\hline Vega (\% of the CEO's salary + bonus) & 0.0060 & 0.8353 & 0.0159 & 0.5804 \\
\hline Log likelihood & 11.7205 & & 11.7284 & \\
\hline Number of observations & 239 & & 239 & \\
\hline Non-limit observations & 83 & & 83 & \\
\hline Censored observations & 156 & & 156 & \\
\hline
\end{tabular}


Table III-Continued

\begin{tabular}{|c|c|c|c|c|}
\hline & $\begin{array}{c}\text { OLS } \\
\text { Estimate }\end{array}$ & $p$-value & $\begin{array}{c}\text { OLS } \\
\text { Estimate }\end{array}$ & $p$-value \\
\hline \multicolumn{5}{|c|}{ Dependent variable: Debt-to-asset ratio } \\
\hline Intercept & 0.3487 & 0.0000 & 0.3890 & 0.0000 \\
\hline Net derivatives* & 0.3218 & 0.0462 & -0.1932 & 0.0039 \\
\hline Investment tax credits & -9.0471 & 0.0626 & -3.3462 & 0.3675 \\
\hline Intangible assets & 0.2903 & 0.0130 & 0.2829 & 0.0058 \\
\hline R\&D-to-assets & -0.2488 & 0.0013 & -0.2757 & 0.0040 \\
\hline SG\&A expense & -0.1511 & 0.0328 & -0.1913 & 0.0057 \\
\hline Log(Sales) & -0.0151 & 0.0406 & -0.0439 & 0.0000 \\
\hline Volatility & 0.0020 & 0.3958 & 0.0042 & 0.0597 \\
\hline Marginal tax rate (MTR) & -0.0491 & 0.7542 & 0.5355 & 0.0038 \\
\hline Net derivatives $* \times$ MTR & & & 4.2506 & 0.0000 \\
\hline Negative book-market dummy & 0.6069 & 0.0000 & 0.4383 & 0.0000 \\
\hline Net PP\&E & 0.1368 & 0.0395 & 0.1521 & 0.0188 \\
\hline Number of observations & 249 & & 249 & \\
\hline Adjusted $R$-squared & 0.4856 & & 0.595 & \\
\hline
\end{tabular}

In the second stage, structural equations are estimated using the predicted values from the first-stage regressions as explanatory variables. To save space, we focus on the second stage of the simultaneous equations system.

\section{A.1. Tax Results}

The estimated coefficients in the second-stage hedging equation are shown in Table III. Of particular interest, the coefficient on the tax convexity variable is negative and statistically insignificant. This is the first direct evidence that firms do not hedge in response to tax function convexity. To further explore convexity incentives, in unreported analysis, we use several variations of the convexity variable. First, we find that dummy variables indicating "high" levels of convexity (values greater than the median, 75th, and 90th percentiles) are not significantly related to derivatives hedging. The coefficients are also insignificant if the high-convexity dummies are interacted with the actual convexity values. We also use other nonlinear specifications. In one specification, we define a new variable equal to the square root of the convexity variable when it is positive, and equal to zero otherwise. In a separate test, we use the square of the convexity variable. Neither of these nonlinear convexity variables shows a significant relation with derivatives hedging.

Second, the coefficient on the predicted value of the debt ratio in column 1 is positive and significant, indicating that high debt ratios contribute to the incentive to hedge. In Section A.3, we discuss in more detail this evidence that hedging increases in response to expected distress costs. 
Third, in the second-stage debt regression, the predicted extent of derivatives hedging is positively related to the debt ratio. This is the first evidence that hedging increases the debt ratio and consequently increases value through the tax benefit of interest deductions. We find the same positive "hedging causes debt" effect in an unreported regression that measures leverage with debt-to-value, instead of debt-to-assets. These results have important implications for capital structure research because they highlight a previously undocumented influence on debt policy, namely, corporate hedging practices. A complete modeling of capital structure decisions needs to consider corporate hedging or it risks omitting an important variable.

Though Leland (1998) and Ross (1997) suggest that firms hedge to increase debt capacity because of tax incentives, this relation could also be driven by nontax factors. For example, an untaxed firm might hedge to increase debt capacity and use this external funding to invest in profitable projects, even though it does not benefit from the interest tax deductions. To investigate the relative importance of tax and nontax incentives in the positive "hedging causes debt" result, we include a variable that interacts the hedging variable with the marginal tax rate, and repeat the regressions. That is, among the Table III, Model 2, explanatory variables, we include predicted net derivatives, the corporate marginal tax rate, and a new variable that interacts the two.

The results strongly suggest that tax incentives are behind the "hedging causes debt" result: The coefficient on predicted net derivatives is -0.19 $(t$-score of -2.9$)$ and the coefficient on predicted net derivatives multiplied by the marginal tax rate is 4.25 ( $t$-score of 5.3 ). This indicates that the incentive to hedge to increase debt capacity is positively related to the corporate marginal tax rate. Taking the partial derivative with respect to the net derivatives variable, the effect of hedging to increase debt capacity is positive for firms with tax rates greater than 4.5 percent. The incentive to hedge to increase debt capacity appears to be tax motivated.

\section{A.2. How Big Are the Tax Benefits of Hedging?}

Our evidence implies that firms hedge to increase debt capacity but not in response to tax function convexity. Although there may be other benefits, the central motive for increasing debt capacity in several models of corporate hedging is to increase tax deductions (e.g., Stulz (1996), Ross (1997), and Leland (1998)). We now quantify the size of the tax benefit provided by increased debt capacity and contrast it with the potential benefit associated with tax function convexity.

Hedging increases the average (median) firm's debt ratio by 3.03 percent (2.46 percent) (see the first column of Table IV). We calculate these figures by multiplying the estimated influence of hedging on the debt ratio (i.e., the estimated coefficient on net derivatives in the Table III debt regression) by each firm's actual scaled net holdings of derivatives. The mean and median increases in the debt ratios are statistically different from zero according to a $t$-test and a Wilcoxon rank-sum test, respectively (not reported). 
Table IV

\section{Quantifying the Tax Advantage of Hedging with Derivatives}

Table IV summarizes tax savings associated with derivatives hedging. The first column shows the distribution of the product of firm-specific values of net derivatives scaled by book value of assets and the OLS coefficient on the derivatives variable from the second-stage debt regression (the coefficient is taken from Model 1, Table III). This product represents the portion of the long-term debt ratio that is attributable to derivatives hedging. The numbers in the second column are the product of values from the first column (multiplied by total assets) and marginal tax rates, where DTB stands for debt tax benefit. The third column scales the values in the second column by the market value of the firm's assets (lagged one year). The rightmost column shows the distribution of the absolute value of the expected dollar reduction in expected tax liabilities resulting from a 5 percent reduction in the volatility of sales revenue discounted as a perpetuity (using a 10 percent discount rate), scaled by lagged market value.

\begin{tabular}{lcccc}
\hline & $\begin{array}{c}\text { Portion of Debt } \\
\text { Ratio Attributable } \\
\text { to Hedging to } \\
\text { Increase Debt } \\
\text { Capacity }\end{array}$ & $\begin{array}{c}\text { Dollars of } \\
\text { DTB Due to } \\
\text { Hedging to } \\
\text { Increase Debt } \\
\text { Capacity (Millions) }\end{array}$ & $\begin{array}{c}\text { Contribution } \\
\text { of DTB to } \\
\text { Market Value }\end{array}$ & $\begin{array}{c}\text { Potential } \\
\text { Of Tax Function } \\
\text { Convexity to } \\
\text { Market Value }\end{array}$ \\
\hline$N$ & 85 & 85 & 84 & 84 \\
Mean & $3.03 \%$ & $\$ 31.87$ & $1.11 \%$ & $0.306 \%$ \\
Median & $2.46 \%$ & $\$ 9.80$ & $0.72 \%$ & $0.072 \%$ \\
Std. Dev. & $3.11 \%$ & $\$ 50.47$ & $1.75 \%$ & $0.738 \%$ \\
99th percentile & $17.32 \%$ & $\$ 275.80$ & $14.85 \%$ & $6.055 \%$ \\
95th percentile & $9.06 \%$ & $\$ 140.85$ & $2.98 \%$ & $1.240 \%$ \\
90th percentile & $6.56 \%$ & $\$ 75.82$ & $2.19 \%$ & $0.862 \%$ \\
75th percentile & $3.63 \%$ & $\$ 33.30$ & $1.29 \%$ & $0.229 \%$ \\
25th percentile & $0.89 \%$ & $\$ 3.73$ & $0.23 \%$ & $0.037 \%$ \\
10th percentile & $0.30 \%$ & $\$ 1.48$ & $0.08 \%$ & $0.018 \%$ \\
5th percentile & $0.19 \%$ & $\$ 0.55$ & $0.05 \%$ & $0.014 \%$ \\
1st percentile & $0.00 \%$ & $\$ 0$ & $0.00 \%$ & $0.009 \%$ \\
\hline
\end{tabular}

In column 2 of Table IV, we multiply the incremental debt usage of each firm by its marginal tax rate to determine the tax benefit of the extra debt firms use when they hedge. This is just an application of the traditional "corporate tax rate times debt" formula to estimate the capitalized tax benefits provided by debt (see Graham (2000)). Note that we use the simulated marginal tax rates computed by Graham et al. (1998), which capture the probability that tax benefits might not be fully realized, rather than the textbook approach of using the statutory tax rate. The mean incremental tax benefit provided by hedging is approximately $\$ 31.87$ million, and the median value is $\$ 9.8$ million.

In the third column of Table IV, we scale each firm's incremental debt tax benefit (DTB) from hedging by its market value of assets from the prior year. The mean (median) tax benefits of increased debt capacity amount to 1.11 percent ( 0.72 percent) of the market value of assets. Thus, the typical tax benefit of hedging to increase debt capacity contributes value of the same magnitude as the numerical examples in Leland (1998). The tax ben- 
efits are at least 3.0 percent of value for 1 out of 20 firms. To the extent that there are also nontax benefits, these numbers are conservative estimates of the benefits of hedging to increase debt capacity.

As a point of comparison, we calculate the tax benefits achievable if firms were to manage risk in response to tax function convexity or concavity (see column 4 from Table IV). We assume that the dollar savings from convexity are a perpetuity discounted at 10 percent. For the average firm, the numbers imply that a firm hedging to reduce volatility by 5 percent would reduce tax liabilities by approximately 0.306 percent of firm value. This indicates that the tax incentive to hedge in response to tax function convexity is roughly one-fourth the incentive to increase debt capacity. This might explain why our analysis documents a tax incentive to hedge to increase debt capacity but not an incentive to hedge in response to tax function convexity.

The numbers in Table IV represent the gross tax benefits of hedging. We assume that firms choose an optimal hedging policy by setting their marginal benefit equal to marginal cost. To get a rough estimate of the costs of hedging, we use the numbers derived by Brown (2001) for HDG Inc. (a pseudonym). HDG has a very large hedging operation (approximately $\$ 1.1$ billion in notional value of derivatives at year-end 1994). Brown estimates that the costs of hedging operations (salaries, fixed costs, etc.) for HDG are \$1.5 million, and the trading costs are $\$ 2.3$ million. Capitalizing the total costs of $\$ 3.8$ million at an assumed discount rate of 10 percent yields present value hedging costs of $\$ 38$ million.

We examine the five sample firms with the smallest absolute difference from HDG's notional holdings. Given the comparable size of holdings, we use HDG's costs to benchmark the relative tax benefits of hedging for these firms. The name, notional value, and tax benefits from hedging for these five firms are:

1. Goodyear, $\$ 1.234$ billion, $\$ 106$ million;

2. Monsanto, $\$ 0.931$ billion, $\$ 77$ million;

3. Coastal, $\$ 1.136$ billion, $\$ 69$ million;

4. Reynolds Metals, $\$ 1.495$ billion, $\$ 62$ million; and

5. GATX, $\$ 1.3$ billion, $\$ 33$ million.

The debt tax benefits from hedging are greater than the estimated $\$ 38$ million costs for four of the five firms. Even for the one exception (GATX), total benefits likely exceed total costs of hedging because tax savings are only one of several potential benefits of hedging.

\section{A.3. Nontax Results}

The estimated coefficients in Table III show that the debt ratio and the interaction of debt with market-book are both positively related to hedging. These findings are consistent with firms hedging in response to large expected costs of distress. In contrast, the negative coefficient on the NOL carryforward variable indicates that firms reduce hedging if they recently 
accumulated losses. Though inconsistent with hedging in response to past distress, this relation may indicate that the option value of equity discourages severely distressed firms from hedging. Note that many previous papers would interpret the NOL result in terms of tax function convexity. Because we directly measure convexity, our analysis suggests that NOLs capture a separate, nontax influence on hedging behavior.

We find a negative relation between $R \& D$ expenses and hedging, and a positive relation between the book-market ratio and hedging. Neither of these results is consistent with underinvestment costs leading to hedging. ${ }^{20} \mathrm{How}-$ ever, like Géczy et al. (1997), we find a positive relation between hedging and the product of the debt and market-book ratios, which is consistent with firms hedging to minimize underinvestment problems when they have growth options (Bessembinder (1991), and Froot et al. (1993)).

The coefficient on vega is insignificant, providing no evidence that executives reduce hedging when increased firm volatility would increase their personal wealth. In contrast, the coefficient on the delta of CEO's stock and option holdings is positively related to derivatives hedging (significant at 10 percent). To the best of our knowledge, this is the first evidence linking corporate hedging to the Core and Guay (1999) measures of the sensitivity of managerial stock/option holdings. ${ }^{21}$

Hedging increases with firm size. This result is consistent with fixed costs limiting hedging by small firms, but not consistent with informational asymmetry leading to increased hedging. The positive relation between hedging and institutional ownership is also not consistent with the informational asymmetry hypotheses. This latter finding confirms in the broad cross section what Géczy et al. (1997) find for Fortune 500 firms.

\section{B. Robustness Checks}

There could be a positive relation between the use of IR derivatives and the debt variables simply because high-debt firms have more liabilities to hedge and not because of financial distress. To address this concern, we perform Tobit analysis on the IR sample, scaling interest rate derivatives by debt, rather than by assets. This specification measures hedging per dollar of debt. (Note that this might "over correct" the problem and induce a neg-

\footnotetext{
${ }^{20}$ We examine the $R \& D$ result in more detail. Like previous research, we find a positive relation between $R \& D$ spending and currency hedging (in an unreported analysis of the FX risk sample). In contrast, we find a negative relation between $R \& D$ and hedging in the second-stage analysis of the IR risk sample. Recall that we have already shown that debt and hedging are positively related. If underinvestment costs cause a negative relation between debt and R\&D (Myers (1977)), then this could induce a negative relation between R\&D and hedging. In an attempt to remove the effect of the debt/hedging relation on the hedging/R\&D coefficient, in unreported analysis we regress hedging per dollar of debt on R\&D and the other explanatory variables. In this specification, we find no relation between IR hedging and R\&D expense.

${ }^{21}$ In unreported analysis, we find that the logarithm of CEO stock holdings is positively related to our measure of hedging. We find no significant association between CEO option holdings and hedging.
} 
ative coefficient on the independent variables that involve the debt ratio because debt is in the denominator of the dependent variable.) The untabulated results still show a positive, significant relation between leverage and hedging per dollar of debt, corroborating our main findings. ${ }^{22}$

Because the literature offers little precedent in defining ex ante interest rate risk, we examine an alternative definition of interest rate exposure. Given that financial leverage is a possible source of interest rate risk, in the alternative definition of interest rate risk, we classify firms with debt-toassets ratios greater than 10 percent as being interest rate sensitive. While this cutoff point is arbitrary, only 6 of the 97 firms with debt-to-assets ratios less than 10 percent use IR derivatives. Our qualitative results are similar using this alternative definition of ex ante interest rate risk exposure.

Many cross-sectional studies (Nance et al. (1993), Mian (1996), and Géczy et al. (1997)) examine the yes/no hedging decision. In contrast, we use a continuous dependent variable, enabling us to incorporate more information into the dependent variable. Nonetheless, to benchmark to previous analysis, we perform Probit analysis on our sample using a binary dependent variable. Likewise, several studies use total notional values in their definition of a continuous dependent hedging variable. Again to benchmark, we perform the simultaneous regressions using total notional values to define the dependent variable. In both of these robustness checks, the tax results are unchanged, indicating that they are qualitatively robust to different definitions of hedging with derivatives. We prefer the net derivatives specification over the binary specification because it allows for variation in the amount of derivatives, and therefore variation in the tax benefits from hedging. ${ }^{23}$ The total derivatives specification implies that the tax benefits of hedging increase firm value by 2.1 percent on average, so the net derivative results that we report are a conservative estimate of the tax benefits of hedging.

Finally, we run the simultaneous equations system on the FX sample using the binary hedging variable as the dependent variable. We perform this analysis because Géczy et al. (1997) do not find that currency hedging significantly increases the debt ratio in their second-stage regression. Note that our simultaneous system of equations tests whether the extent of hedging affects the debt ratio, while Géczy et al. test whether the probability of hedging affects the debt ratio. In an unreported simultaneous equations regression system using a binary hedging variable (like in Géczy et al.), we no longer find that currency hedging significantly increases the debt ratio in

\footnotetext{
${ }^{22}$ With respect to FX risk, there could be a negative relation between debt and derivatives use if foreign debt substitutes for currency hedging, as argued by Allayannis and Ofek (2001) and Géczy et al. (1997). To the extent that this substitution occurs, it reduces the power of our tests to detect a positive relation between hedging and debt.

${ }^{23}$ Five variables that are statistically significant when we use net derivatives as the dependent variable are not significant when we estimate the hedging equation using a binary dependent variable: predicted debt interacted with market-book, R\&D expense, negative marketbook equity, institutional ownership, and Core and Guay (1999) delta.
} 
the second-stage regression. This indicates that it is not the yes/no decision of whether to hedge, but rather how much a firm hedges, that increases debt capacity.

\section{Conclusion}

We investigate whether firms use derivatives to implement risk management strategies in response to tax incentives. Although derivatives offer only one means for managing risk, the relatively low transactions costs of engaging in a derivatives program make this an ideal setting to study corporate hedging practices. For example, we find that the costs are smaller than the tax benefits of hedging for four out of five "case studies" that we examine. Another reason to study derivatives when analyzing corporate risk management is because they are disclosed in financial statements, while other hedging strategies are more difficult to observe.

We find evidence that firms hedge to increase debt capacity and interest deductions. In particular, we estimate that the tax benefits resulting from hedging add approximately 1.1 percent to firm value. To our knowledge, these are the most explicit estimates of the benefits of hedging in response to a specific theory of why firms hedge. Moreover, this result identifies a previously undocumented link between hedging and capital structure. This implies that a complete modeling of corporate debt policy should control for the influence of hedging decisions.

In contrast, we find no evidence that firms hedge to reduce expected tax liability when their tax functions are convex. This analysis represents the first time that the convexity hypothesis has been tested using an explicit measure of tax function convexity. This result is consistent with practitioner descriptions of the reasons that firms hedge. Our interpretation is that firms do not hedge in response to convexity because the incentive is small relative to other hedging incentives. Another possibility is that firms reduce income volatility by means other than using derivatives. For example, accounting policies can be used to smooth taxable income through time. Petersen and Thiagarajan (2000) note that Homestake Mining, which faces substantial gold price risk but does not hold derivatives, uses accounting policies that effectively increase taxable income during periods of low gold prices and decrease income during periods of high prices.

We close by noting that FASB implemented SFAS 133 on June 15, 2000, to supersede SFAS 119. SFAS 133 requires firms to report the fair market values of derivative contracts but does not require the disclosure of notional values. Fair values of derivatives measure the amount that the contract holder would receive, or pay, to liquidate a contract. Therefore, fair values provide information on the extent of price movements in derivative contracts, rather than the amount of derivatives held. (For example, many derivatives have a market value of zero at origination, in which case fair market value reveals little, if anything, about derivatives usage.) The ability of in- 
vestors, regulators, and researchers to determine the extent of corporate derivative holdings could be undermined if FASB no longer requires firms to report notional values.

\section{REFERENCES}

Allayannis, George and Eli Ofek, 2001, Exchange rate exposure, hedging, and the use of foreign currency derivatives, Journal of International Money and Finance 20, 273-296.

Allayannis, George and James Weston, 2001, The use of foreign currency derivatives and firm market value, Review of Financial Studies 14, 243-276.

Berkman, Henk, and Michael E. Bradbury, 1996, Empirical evidence on the corporate use of derivatives, Financial Management 25, 5-13.

Bessembinder, Hendrik, 1991, Forward contracts and firm value: Investment incentive and contracting effects, Journal of Financial and Quantitative Analysis 26, 519-532.

Bicksler, James, and Andrew H. Chen, 1986, An economic analysis of interest rate swaps, Journal of Finance 41, 645-655.

Bodnar, Gordon M., Gregory S. Hayt, and Richard C. Marston, 1996, 1995 Wharton survey of derivatives usage by U.S. non-financial firms, Financial Management 25, 113-133.

Breeden, Douglas, and S. Viswanathan, 1998, Why do firms hedge? An asymmetric information model, Working paper, Duke University.

Brown, Gregory W., 2001, Managing foreign exchange risk with derivatives, Journal of Financial Economics 60, 401-448.

Core, John, and Wayne Guay, 1999, A new, low-cost proxy for the incentive effects of stock option portfolios, Working paper, University of Pennsylvania.

DeMarzo, Peter M., and Darrell Duffie, 1991, Corporate financial hedging with proprietary information, Journal of Economic Theory 53, 261-286.

Dolde, Walter, 1995, Hedging, leverage, and primitive risk, Journal of Financial Engineering 4, $187-216$.

Fenn, George W., Mitch Post, and Steven A. Sharpe, 1996, Debt maturity and the use of interest rate derivatives, Working paper, Federal Reserve Board.

Financial Accounting Standards Board, 1994, Disclosure about derivative financial instruments and fair value of financial instruments, Statement No. 119.

Financial Accounting Standards Board, 1998, Accounting for derivative instruments and hedging activities, Statement No. 133.

Froot, Kenneth A., David S. Scharfstein, and Jeremy C. Stein, 1993, Risk management: Coordinating corporate investment and financing policies, Journal of Finance 48, 1629-1658.

Gay, Gerald D., and Jouahn Nam, 1999, The underinvestment problem and corporate derivatives use, Financial Management 27, 53-69.

Géczy, Christopher, Bernadette A. Minton, and Catherine Schrand, 1997, Why firms use currency derivatives, Journal of Finance 52, 1323-1354.

Graham, John R., 2000, How big are the tax benefits of debt? Journal of Finance 55, 1901-1941.

Graham, John R., 2001, Taxes and corporate finance: A review, Working paper, Duke University.

Graham, John R., Michael L. Lemmon, and James S. Schallheim, 1998, Debt, leases, taxes, and the endogeneity of corporate tax status, Journal of Finance 53, 131-162.

Graham, John R., and Clifford W. Smith, Jr., 1999, Tax incentives to hedge, Journal of Finance $54,2241-2262$.

Guay, Wayne R., 1999, The impact of derivatives on firm risk: An empirical examination of new derivatives users, Journal of Accounting and Economics 26, 319-351.

Harris, Milton, and Artur Raviv, 1991, The theory of capital structure, Journal of Finance 46, $297-355$.

Haushalter, G. David, 2000, Financing policy, basis risk, and corporate hedging: Evidence from oil and gas producers, Journal of Finance 55, 107-152.

Hentschel, Ludger and S. P. Kothari, 2001, Are corporations reducing or taking risks with derivatives? Journal of Financial and Quantitative Analysis 36, 93-118. 
Leland, Hayne E., 1998, Agency costs, risk management, and capital structure, Journal of Finance 53, 1213-1243.

Maddala, G. S., 1983, Limited Dependent and Qualitative Variables in Econometrics (Cambridge University Press, Cambridge, U.K.).

Mian, Shehzad, 1996, Evidence on corporate hedging policy, Journal of Financial and Qualitative Analysis 31, 419-439.

Miller, Merton H., and Franco Modigliani, 1961, Dividend policy, growth, and the valuation of shares, Journal of Business 34, 411-433.

Modigliani, Franco, and Merton H. Miller, 1958, The cost of capital, corporation finance and the theory of investment, American Economic Review 48, 261-297.

Myers, Stewart C., 1977, Determinants of corporate borrowing, Journal of Financial Economics 5, 147-175.

Myers, Stewart C., and Nicholas S. Majluf, 1984, Corporate financing and investment decisions when firms have information that investors do not have, Journal of Financial Economics 13, 187-221.

Nance, Deana R., Clifford W. Smith, Jr., and Charles W. Smithson, 1993, On the determinants of corporate hedging, Journal of Finance 48, 267-284.

Petersen, Mitchell, and S. Ramu Thiagarajan, 2000, Risk measurement and hedging: With and without derivatives, Financial Management 29, 5-30.

Ross, Michael P., 1997, Corporate hedging: What, why and how?, Working paper, University of California, Berkeley.

Schrand, Catherine M., 1998, Discussion: Who uses interest rate swaps? A cross-sectional analysis, Journal of Accounting, Auditing, and Finance 13, 201-205.

Schrand, Catherine, and Haluk Unal, 1998, Hedging and coordinated risk management: Evidence from thrift conversions, Journal of Finance 53, 979-1013.

Smith, Clifford W. Jr., 1995, Corporate risk management: Theory and practice, Journal of Derivatives 2, 21-30.

Smith, Clifford W., Jr., and René M. Stulz, 1985, The determinants of firms' hedging policies, Journal of Financial and Quantitative Analysis 20, 391-405.

Stulz, René M., 1984, Optimal hedging policies, Journal of Financial and Quantitative Analysis 19, 127-140.

Stulz, René M., 1996, Rethinking risk management, Journal of Applied Corporate Finance 9, 8-24.

Titman, Sheridan, 1992, Interest rate swap and corporate financing choices, Journal of Finance 47, 1503-1516.

Titman, Sheridan, and Roberto Wessels, 1988, The determinants of capital structure choice, Journal of Finance 43, 1-19.

Tufano, Peter, 1996, Who manages risk? An empirical examination of risk management practices in the gold mining industry, Journal of Finance 51, 1097-1137.

Tufano, Peter, 1998, Agency costs of corporate risk management, Financial Management 27, 67-77.

Visvanathan, Gnanakumar, 1998, Who uses interest rate swaps? A cross-sectional analysis, Journal of Accounting, Auditing, and Finance 13, 173-200.

Wong, M. H. Franco, 2000, The usefulness of SFAS 119 derivatives disclosures for assessing the foreign exchange risk exposure of manufacturing firms, Journal of Accounting Research 38, 387-417. 
